\title{
The Treatment of Internet Gaming Disorder: a Brief Overview of the PIPATIC Program
}

\author{
Alexandra Torres-Rodríguez ${ }^{1} \cdot$ Mark D. Griffiths $^{2}$ (D) \\ Xavier Carbonell ${ }^{1}$
}

(C) The Author(s) 2017. This article is an open access publication

\begin{abstract}
Over the last decade, there has been an increase in children and adolescents accessing psychology services regarding problematic use of online videogames. Consequently, providing effective treatment is essential. The present paper describes the design process of a manualized PIPATIC (Programa Individualizado Psicoterapéutico para la Adicción a las Tecnologías de la información y la comunicación) intervention program for 12- to 18-year-old adolescents with Internet Gaming Disorder. The design and application of the PIPATIC program integrates several areas of intervention structured into six modules: psychoeducational, treatment as usual, intrapersonal, interpersonal, family intervention, and development of a new lifestyle. The program's goals are to reduce the addiction symptoms related to online videogames and to improve the well-being of adolescents. Preliminary findings suggest positive and encouraging effects.
\end{abstract}

Keywords Internet addiction · Gaming addiction · Online videogames · Cognitive behavioral therapy · Manualized treatment · Internet Gaming Disorder

Information and communication technologies (ICTs) have become fully integrated in people's day-to-day lives. The increasing engagement in social networking, online videogame playing, and using smartphone applications has brought about new interaction styles. One group that often uses such online applications in both positive and negative ways are adolescents (Kuss and Griffiths 2012; Kuss and Griffiths 2017). On the positive side, online applications have been beneficial in research, science, medical, scholar, social networking, etc. On the negative

Alexandra Torres-Rodríguez

alexandrart@blanquerna.url.edu

1 Universitat Ramon Llull, C. Císter 34, 08022 Barcelona, Spain

2 International Gaming Research Unit, Psychology Department, Nottingham Trent University, 50 Shakespeare Street, Nottingham NG1 4FQ, UK 
side, excessive use may lead to negative consequences such as addictive behaviors among a small minority of users (Kowert et al. 2014; Williams et al. 2008).

\section{Online Videogames}

The main objective of playing videogames is to entertain users via interactive systems that have now been developed across multiple platforms (e.g., personal computer, game consoles, mobile phones, and tablets). At present, most videogame applications have been developed with good online accessibility and accompanying social platforms (e.g., Twitch, Steam, and Origin). Consequently, there are hundreds of genres and sub-genres of online videogames. These genres include (i) massively multiplayer online role-playing games (MMORPGs), such as World of Warcraft (WoW); (ii) multiplayer online battle arena (MOBA) games, such as League of Legends (LoL); and (iii) first-person shooter (FPS) games such as action games like Battlefield (BT), Counter Strike (CS), and Call of Duty (CoD). There are also "social" videogames, such as Angry Birds, which are usually very simple and quick to play and have been developed to play via social networks and smartphones (Carbonell et al. 2016). At present, MOBA games are among the most popular. Its increasing popularity may be due to its structural characteristics such as the high level of competitiveness and free-to-play modes, and situational characteristics such as its high accessibility (Griffiths and Nuyens 2017). In spite of that, the MMORPGs are still popular with millions of players.

However, such classification may become less important due to the way new games are evolving. Newer games have begun to incorporate multiple genres and game modes simultaneously: action games (survival, shooter, platform, etc.), simulation games (vehicle, life, and construction simulation), role-playing games (MMORPGs), strategy games (MOBA, wargames, etc.), adventure games, sports games, cooperative games, and casual games. For example, Day Z, Star Citizen, and Minecraft are current online games with multiple genres and game modes. Furthermore, videogames are becoming more realistic and complete, offering users immersive playability.

There is also increasing convergence between online gaming and other online activities such as gambling, activities that are primarily based on positive and negative reinforcement. Other similar characteristics include the following: (i) high sociability, (ii) multiplayer features, (iii) potential for high immersion in virtual environments, (iv) creation of one's own virtual identity and/or character development, and (v) possibility of infinite duration within a 24/7 environment (Griffiths and Nuyens 2017; King et al. 2010b; Wood et al. 2004). All five of these things can be found in online gambling.

Current models suggest that some structural characteristics of online video games have the capacity to contribute to the development of a problematic use and/or addictive behaviors leading to a deterioration in the self-control of behavior and quality of life (Carbonell et al. 2012; Fuster et al. 2016; Nuyens et al. 2016). To understand this relationship, it is important consider the problem from an eclectic and multidisciplinary perspective, including those working from a clinical mental health perspective.

\section{Clinical Psychology Perspective on Problematic Gaming}

A good clinician will always try to understand the many aspects that may influence the acquisition, development, and maintenance of problematic online videogame use. Many 
researchers advocate a biopsychosocial model in explaining the interaction between different risk factors (e.g., Kelly 2004; Kuss and Griffiths 2012; Mazurek and Engelhardt 2013; Rehbein et al. 2010; Wittek et al. 2015; Yee 2006). Table 1 lists many of the main risk factors in the development of problematic online gaming.

Online gaming addiction has been associated with (and may initiate) other comorbid mood disorders such as depression, stress, and anxiety disorders (Ferguson et al. 2011; King and Delfabbro 2014; Pontes et al. 2014). Consequently, videogame addiction in the form of Internet Gaming Disorder (IGD) was included in Section 3 of the latest (fifth) revision of the Diagnostic and Statistical Manual of Mental Disorders (DSM-5; American Psychiatric Association 2013). The clinical diagnosis of IGD comprises persistent and recurrent use of the Internet to engage in games, leading to clinically significant impairment or distress over a period of 12 months as indicated by five (or more) of the following criteria: (i) pre-occupation with Internet games; (ii) withdrawal symptoms when Internet gaming is taken away; (iii) tolerance or, in other words, the need to increase the time devoted to videogames; (iv) unsuccessful attempts to control participation in Internet games; (v) loss of interests in previous hobbies and entertainment as a result of, and with the exception of, Internet games; (vi) continued excessive use of Internet games despite knowledge of psychosocial problems; (vii) deceiving family members, therapists, or others regarding the amount of Internet gaming; (viii) use of Internet games to escape or relieve negative moods; and (ix) jeopardizing or losing a significant relationship, job, or education or career opportunity because of participation in Internet games. The criteria proposed by the APA ( 2013) appear to have adequate validity and diagnostic precision (Ko et al. 2014). Its prevalence, according to the American Psychiatric Association (2013), is between 1 and $7 \%$. Part of this variation is due to the fact that different instruments are used in different cultural contexts and for different ages (Feng et al. 2017; Ferguson et al. 2011; Müller et al. 2015; van Rooij et al. 2014).

According to Griffiths, King, and Demetrovics (Griffiths et al. 2014), the inclusion of IGD in the DSM-5 provided the opportunity for consensus and unification in the field. However, there is still no consensus on many issues related to the DSM-5 diagnostic criteria for IGD, and its psychological, social, and health consequences still require further study (Griffiths et al. 2016b; Király et al. 2015; Kuss et al. 2016). The lack of consensus concerning diagnostic criteria makes the work of clinical psychologists and other therapists difficult. Consequently, there is a need to clearly define IGD, clarify its most controversial aspects, and expand the study of specialized IGD treatments.

Table 1 Selective important risk factors in addiction to online videogames

1) Biological factors

- Vulnerability to addictions

- Deficits in neurotransmitters

- Psychiatric comorbidity: depression, anxiety, ADHD, ASD, etc.

2) Personality and psychological vulnerability factors

- Immaturity

- Emotional instability

- Unconsolidated identity

- Low self-esteem and indecision

- Lack of self-control

- Frustration

- Low resilience

- High sensation search

- Deficit of social skills, inhibition and extreme shyness
3) Environmental factors

- Family environment: conflictive, poor communication and affection, lack of supervision and family cohesion, etc.

- School environment with low performance, demotivation, etc.

- Poor social environment

4) Stress factors

- Grief

- Major crises

- Drastic life changes

5) Structural factors 


\section{Psychological Treatment for Internet Gaming Disorder}

Although the study of IGD has grown markedly in recent years (Griffiths et al. 2016a; Kuss and Griffiths 2012), evaluations of psychological treatments are still scarce. The most used treatment for online addictions appears to be cognitive behavioral therapy (CBT) based on the peer-reviewed literature (Greenfield 1999a, 1999b; Griffiths and Meredith 2009; Kaptsis et al. 2016; King et al. 2010b, 2011; Young 2007, 2013). Other treatments used include pharmacotherapy (methylphenidate and bupropion) and counseling (King et al. 2011). Most of the therapeutic recommendations are based on substance abuse treatment (Huang et al. 2010; King et al. 2011) including motivational interviewing techniques, stimulus control, learning appropriate coping responses, self-monitoring strategies, cognitive restructuring, problem-solving related to addiction, and withdrawal regulation techniques with exposure (Griffiths and Meredith 2009; King et al. 2010a; Young 2007). Furthermore, there has been little evaluation concerning the efficacy of different psychological interventions with children and adolescents (King et al. 2013; King and Delfabbro 2016).

With regard to clinical practice, therapies for IGD based on substance abuse treatment have a number of limitations. One of the most important is the high rate of comorbid disorders with IGD that could influence the effect of the treatment. Some of the most common disorders associated with IGD include anxiety disorders, mood disorders, behavioral disorders, autism spectrum disorder (ASD), attention deficit hyperactivity disorder (ADHD), and personality disorders (Ferguson et al. 2011; Gentile et al. 2011; Han et al. 2014; Kelleci and Inal 2010; Ko et al. 2006; Shapira et al. 2000). Most published IGD treatment studies have not taken into account these comorbidities; therefore, more integrated and comprehensive treatments taking these comorbid disorders into account would improve treatment outcomes for such individuals (Therien et al. 2014).

Consequently, there is both an empirical and clinical need to generate specialized, integrated, and comprehensive treatment protocols taking into account the specific characteristics of IGD along with its associated comorbid disorders. Furthermore, it is clinically important to develop treatments for adolescents. In recent years, psychiatric wards have reported an increase of consultations regarding adolescents with problematic use of cyber-technologies (Beranuy et al. 2012). On the other hand, the adolescent population regularly uses online video games and they also present with multiple psychological vulnerabilities that are intrinsic to this life stage.

As a result, the aim of the present paper describes a specialized and integrative treatment program based on the scientific and clinical need to design treatments specifically for the adolescent population with IGD. The treatment program provides essential and common factors concerning IGD and was developed for health professionals to utilize in the treatment of IGD in adolescence.

\section{Stage I: Designing and Developing the Treatment Program}

To develop bespoke psychotherapy (in this case, for IGD), manuals in clinical practice must be followed to define guidelines and strategies from basic outlines in order to promote empirically supported treatments (Carroll and Nuro 2002). In the development and design of the PIPATIC program, there are common and essential aspects that should be included in any program evaluation report (Moscosoa et al. 2013; Schulz et al. 2010). The word "PIPATIC" is an acronym for "Programa Individualizado Psicoterapéutico para la Adicción a las Tecnologías de la información y la comunicación". The English translation for this Spanish program is "Individualized psychotherapy program for addiction to information and communication technologies." 
The guidelines proposed by Carroll and Nuro (2002) were used for the IGD treatment presented in the present paper due to their rigor and scientific underpinnings. Carroll and Nuro divide the development of treatment manuals into three stages: (i) the development of the treatment and a pilot application, (ii) the design of the methodology with a controlled clinical trial to evaluate the efficacy of the treatment, and (iii) the evaluation of the application of treatment in different contexts and the relationship between their effectiveness and costs.

The goal of the newly developed PIPATIC program (Torres-Rodriguez and Carbonell 2017) is to offer specialized psychotherapy for adolescents with symptoms of IGD and comorbid disorders. This program comprises six therapeutic work modules, in turn comprising further specific sub-objectives. Following previous studies in order to ensure therapeutic change in patients, the duration of the program is six-months (22 weekly sessions each lasting $45 \mathrm{~min}$ ) (Hansen and Lambert 2003; Kadera et al. 1996; Lambert et al. 1994; Seligman 1995). The composition of the modules and sessions is briefly outlined in Tables 2, 3, 4, 5, 6, 7, and 8. Additionally, the PIPATIC program includes two floating sessions that can be incorporated into the module of the therapist's choosing, according to the needs of the patient. In this way, the set program offers some flexibility (Carroll and Nuro 2002; Therien et al. 2014).

Table 2 Module 1: psychoeducation and motivations (three sessions)

\begin{tabular}{|c|c|c|c|}
\hline Sub-modules & Content & Psychological strategies & $\begin{array}{l}\text { Intervention techniques } \\
\text { and strategies }\end{array}$ \\
\hline $\begin{array}{l}\text { Motivational } \\
\text { aspects }\end{array}$ & Motivational interviewing & $\begin{array}{l}\text { Active listening of } \\
\text { the problem } \\
\text { Express empathy } \\
\text { Framing the personal } \\
\text { situation } \\
\text { Working on patient } \\
\text { resistance }\end{array}$ & $\begin{array}{l}\text { Self-motivation } \\
\text { reinforces } \\
\text { Explore ethical and } \\
\text { personal values } \\
\text { Decisional balance }\end{array}$ \\
\hline Goal setting & $\begin{array}{l}\text { Definition of goals in order to } \\
\text { address their problems, to } \\
\text { generate the beginning of change, } \\
\text { promoting organization and } \\
\text { responsibility daily habits }\end{array}$ & $\begin{array}{l}\text { Be an active role in } \\
\text { the negotiations } \\
\text { Confronting } \\
\text { non-therapeutic goals } \\
\text { Make initial requests to } \\
\text { increase their } \\
\text { responsibility and } \\
\text { autonomy }\end{array}$ & $\begin{array}{l}\text { Make a negotiated goal } \\
\text { list with patient, } \\
\text { family and } \\
\text { psychologist } \\
\text { Elaboration of goals } \\
\text { and habits reminder } \\
\text { cards } \\
\text { Schedule with } \\
\text { therapeutic habits }\end{array}$ \\
\hline $\begin{array}{l}\text { Psychoeducation } \\
\text { with the } \\
\text { adolescent }\end{array}$ & $\begin{array}{l}\text { ICTs and videogames: maladaptive } \\
\text { and adaptive use, benefits and } \\
\text { disadvantages } \\
\text { Perception of their reality }\end{array}$ & $\begin{array}{l}\text { Guide and give } \\
\text { self-observation instruc- } \\
\text { tions to explore the use } \\
\text { and knowledge of the } \\
\text { ICTs } \\
\text { Generate awareness of the } \\
\text { problem } \\
\text { Use motivational } \\
\text { techniques }\end{array}$ & $\begin{array}{l}\text { Rhetorical-pragmatic } \\
\text { techniques } \\
\text { Self-registers through } \\
\text { self-observation } \\
\text { Negotiation techniques } \\
\text { Individual } \\
\text { Psychoeducation } \\
\text { Motivational } \\
\text { techniques }\end{array}$ \\
\hline $\begin{array}{l}\text { Family } \\
\text { psychoeducat- } \\
\text { ion }\end{array}$ & $\begin{array}{l}\text { ICTs and videogames: maladaptive } \\
\text { and adaptive use, benefits and } \\
\text { disadvantages }\end{array}$ & $\begin{array}{l}\text { Solve doubts } \\
\text { Contain and regulate } \\
\text { anxieties }\end{array}$ & $\begin{array}{l}\text { Hetero-observation by } \\
\text { the family } \\
\text { Family } \\
\text { Psychoeducation } \\
\text { First guidelines for } \\
\text { rational use of ICTs }\end{array}$ \\
\hline
\end{tabular}


Table 3 Module 2: addictions treatment as usual adapted to IGD (five sessions)

\begin{tabular}{|c|c|c|c|}
\hline Sub-modules & Content & Psychological strategies & $\begin{array}{l}\text { Intervention techniques } \\
\text { and strategies }\end{array}$ \\
\hline $\begin{array}{l}\text { Addiction } \\
\text { stimulus } \\
\text { control }\end{array}$ & $\begin{array}{l}\text { Craving control } \\
\text { Self-control capacity } \\
\text { Irrational beliefs of } \\
\text { self-control }\end{array}$ & $\begin{array}{l}\text { Exemplify real situations } \\
\text { of loss of control } \\
\text { Contain the difficulties } \\
\text { of self-observation } \\
\text { Detection of inappropriate uses } \\
\text { To find relations between } \\
\text { emotions, cognition } \\
\text { and conduct }\end{array}$ & $\begin{array}{l}\text { Stimulus control: establishing } \\
\text { a connection time } \\
\text { Self-registers } \\
\text { Stopping thinking } \\
\text { Positive reinforcement } \\
\text { Self-reinforcement } \\
\text { Tolerance to the frustration } \\
\text { techniques }\end{array}$ \\
\hline $\begin{array}{l}\text { Coping } \\
\text { responses }\end{array}$ & $\begin{array}{l}\text { Inadequate coping } \\
\text { responses related to } \\
\text { the addiction and } \\
\text { low self-control }\end{array}$ & $\begin{array}{l}\text { Guide the reflection about } \\
\text { the relationship with the } \\
\text { addictive behavior } \\
\text { Behaviors and thoughts } \\
\text { interpretation } \\
\text { To promote new adaptive } \\
\text { responses in discomfort } \\
\text { situations }\end{array}$ & $\begin{array}{l}\text { Training in alternative } \\
\text { coping responses } \\
\text { Self-instruction training }\end{array}$ \\
\hline $\begin{array}{l}\text { Cognitive } \\
\text { restructura- } \\
\text { tion }\end{array}$ & $\begin{array}{l}\text { Cognitive distortions } \\
\text { and irrational beliefs } \\
\text { that interfere with } \\
\text { behavior control }\end{array}$ & $\begin{array}{l}\text { Detect and restructure cognitive } \\
\text { distortions and irrational } \\
\text { beliefs } \\
\text { Therapeutic work based on } \\
\text { rational-emotive behavior ther- } \\
\text { apy (Ellis 1990) and cognitive } \\
\text { therapy (Beck 1979) } \\
\text { Exemplify and use metaphors }\end{array}$ & $\begin{array}{l}\text { ABC (A-Activating Event; } \\
\text { B-Belief; C-Consequence) } \\
\text { model explanation } \\
\text { ABC self-registration exercises } \\
\text { Socratic debates } \\
\text { Exercises related to the } \\
\text { imagination of situations and } \\
\text { behavioral testing }\end{array}$ \\
\hline $\begin{array}{l}\text { Problem } \\
\text { solving } \\
\text { related to } \\
\text { addiction }\end{array}$ & $\begin{array}{l}\text { Identify, define, and } \\
\text { solve } \\
\text { addiction-related } \\
\text { problem situations }\end{array}$ & $\begin{array}{l}\text { To guide insights about } \\
\text { discomfort able situations and } \\
\text { the consequences } \\
\text { To teach adequately to deal with } \\
\text { these situations without } \\
\text { resorting to addictive } \\
\text { behaviors such as avoidance, } \\
\text { flight, or stimulation }\end{array}$ & $\begin{array}{l}\text { Identification of problem } \\
\text { situations, involved emotions } \\
\text { and thoughts } \\
\text { Role-playings of the conflictive } \\
\text { real situations with its } \\
\text { alternative responses } \\
\text { List of coping thoughts }\end{array}$ \\
\hline Exposition & $\begin{array}{l}\text { Disappearance of } \\
\text { craving led to } \\
\text { inappropriate } \\
\text { behavior }\end{array}$ & $\begin{array}{l}\text { To guide an exposition process to } \\
\text { transform the compulsive } \\
\text { behavior into adaptively and } \\
\text { controlled activity } \\
\text { To guide the co-therapist in to } \\
\text { exposure process }\end{array}$ & $\begin{array}{l}\text { Imaginative exposure } \\
\text { Co-therapist exposure } \\
\text { Stopping thinking } \\
\text { Remembering coping thoughts } \\
\text { and responses, encourage } \\
\text { self-observation, reinforcement } \\
\text { and self-reinforcement tech- } \\
\text { niques }\end{array}$ \\
\hline
\end{tabular}

One of the main psychological treatments used in the PIPATIC program is CBT given its empirically supported efficacy (Hofmann et al. 2012; Nathan 2015). CBT therapies are commonly used and are effective in the treatment of addictive disorders (Du et al. 2010; King et al. 2012; Li and Wang 2013; Wölfling et al. 2014; Young 2007, 2013). However, the use of multiple psychotherapeutic strategies is considered more effective than one unique perspective (Dong and Potenza 2014; Orzack et al. 2006; Shek et al. 2009; Therien et al. 2014). Consequently, other eclectic and integrative treatment perspectives additional to CBT were included within the PIPATIC program such as motivational interviewing and psychoeducation techniques (see Table 2), strategies derived from person-centered therapy, self-regulation and maturation strategies for adolescents (see Table 4), family therapy (see Table 6), and solution-focused therapy (see Tables 4 and 7). 
Table 4 Module 3: intrapersonal (five sessions)

\begin{tabular}{|c|c|c|c|}
\hline $\begin{array}{l}\text { Sub- } \\
\text { modules }\end{array}$ & Content & Psychological strategies & $\begin{array}{l}\text { Intervention techniques and } \\
\text { strategies }\end{array}$ \\
\hline Identity & $\begin{array}{l}\text { Different levels of identity: } \\
\text { self-ideal, ideal of the } \\
\text { self and self } \\
\text { Self-knowledge through } \\
\text { introspection } \\
\text { Stable identity and identity } \\
\text { regarding addiction }\end{array}$ & $\begin{array}{l}\text { To facilitate and contain the } \\
\text { expression of emotions } \\
\text { To generate connections and } \\
\text { global visions } \\
\text { To ask reflective questions about } \\
\text { identity } \\
\text { To reinforce the process of } \\
\text { personal maturation (solid } \\
\text { personality and autonomy) }\end{array}$ & $\begin{array}{l}\text { Activities related to de } \\
\text { self-knowledge of own identity } \\
\text { Reinforcement } \\
\text { Timeline techniques }\end{array}$ \\
\hline Self-esteem & $\begin{array}{l}\text { The three concepts of the } \\
\text { self (Rogers 1959): } \\
\text { self-image, self-esteem } \\
\text { and ideal-self }\end{array}$ & $\begin{array}{l}\text { To give information about } \\
\text { self-esteem } \\
\text { To guide the change related } \\
\text { himself description } \\
\text { Stimulate positive and proactive } \\
\text { thoughts }\end{array}$ & $\begin{array}{l}\text { Self-affirmation and } \\
\text { self-reinforcement } \\
\text { Establishment and modification of } \\
\text { psychic and physical } \\
\text { self-image through different } \\
\text { activities: incomplete phrases, } \\
\text { self-assessment, analysis of sit- } \\
\text { uations related to the success }\end{array}$ \\
\hline $\begin{array}{l}\text { Emotional } \\
\text { intelli- } \\
\text { gence }\end{array}$ & $\begin{array}{l}\text { To produce self-control } \\
\text { Strategies of } \\
\text { self-management and } \\
\text { emotional regulation }\end{array}$ & $\begin{array}{l}\text { Positive reinforce the patient's } \\
\text { progress } \\
\text { To connect the lack of self-control } \\
\text { and anxiety with the corre- } \\
\text { sponding emotions } \\
\text { To develop the insight and } \\
\text { self-knowledge } \\
\text { To highlight abilities and positive } \\
\text { aspects of the person }\end{array}$ & $\begin{array}{l}\text { Emotional intelligence techniques } \\
\text { Breathing and relaxing techniques } \\
\text { Emotional regulation techniques } \\
\text { and activities } \\
\text { Techniques related to tolerance } \\
\text { discomfort } \\
\text { Mindfulness }\end{array}$ \\
\hline $\begin{array}{l}\text { Emotional } \\
\text { coping } \\
\text { skills }\end{array}$ & $\begin{array}{l}\text { Strategies to generate } \\
\text { adaptive behaviors } \\
\text { Self-management of } \\
\text { anxiety and negative } \\
\text { emotions }\end{array}$ & $\begin{array}{l}\text { To guide in the correct emotional } \\
\text { management } \\
\text { To use real examples discussed } \\
\text { throughout therapy }\end{array}$ & $\begin{array}{l}\text { Training in emotional alternative } \\
\text { responses } \\
\text { Strategies for self-regulation and } \\
\text { self-instruction }\end{array}$ \\
\hline $\begin{array}{l}\text { Problem } \\
\text { solving }\end{array}$ & $\begin{array}{l}\text { Skills and strategies for } \\
\text { solving intrapersonal } \\
\text { problems } \\
\text { Self-management of } \\
\text { conflict situations }\end{array}$ & $\begin{array}{l}\text { To encourage the expression of } \\
\text { anxieties and fears regarding } \\
\text { conflicting vital situations of } \\
\text { the adolescent } \\
\text { To guide the development of } \\
\text { adaptive responses related to } \\
\text { everyday life }\end{array}$ & $\begin{array}{l}\text { Deep understanding of the several } \\
\text { conflicts } \\
\text { Practice the new skills in front } \\
\text { new everyday situations }\end{array}$ \\
\hline
\end{tabular}

The intervention, based on a cognitive behavioral approach, employs cross-cutting techniques and resources common in psychotherapy (Hofmann and Barlow 2014; Kleinke 1994; Laska et al. 2014) including empathy, active and reflexive listening, acceptance, trust, intermediate degree of directivity, paraphrasing, clarification, synthesis, confrontation, interpretation, feedback, promoting abilities, promoting responsibility, encouraging a feeling of self-efficacy, raising insight, and promoting a therapeutic alliance.

At the same time, adolescence is considered to be a vulnerable stage of life, defined by characteristics that generate a high risk of addictive behavior and/or other psychological disorders (Masten and Garmezy 1985; Steinhausen and Metzke 2001). For that reason, the strategies and techniques incorporated into the PIPATIC program have been adapted for adolescents. Consequently, the PIPATIC program is an integrative psychotherapy treatment intervention that focuses on multiple critical areas of the individual. 
Table 5 Module 4: interpersonal (two sessions)

\begin{tabular}{|c|c|c|c|}
\hline Sub-modules & Content & Psychological strategies & $\begin{array}{l}\text { Intervention techniques and } \\
\text { strategies }\end{array}$ \\
\hline Communication & $\begin{array}{l}\text { Interpersonal } \\
\text { communication } \\
\text { Communication styles }\end{array}$ & $\begin{array}{l}\text { To detect if there is any } \\
\text { negative communication } \\
\text { style } \\
\text { To generate a successful } \\
\text { communication with } \\
\text { other people }\end{array}$ & $\begin{array}{l}\text { Psychoeducation about verbal } \\
\text { and nonverbal communication } \\
\text { Role-playings } \\
\text { Activities related to } \\
\text { communication skills }\end{array}$ \\
\hline Assertiveness & $\begin{array}{l}\text { Assertiveness } \\
\text { Basic human rights }\end{array}$ & $\begin{array}{l}\text { To work on building an } \\
\text { assertive belief system } \\
\text { To increase the insight, the } \\
\text { empathy, and } \\
\text { introspection abilities }\end{array}$ & Activities related to assertiveness \\
\hline $\begin{array}{l}\text { Answering } \\
\text { styles }\end{array}$ & $\begin{array}{l}\text { Answering styles } \\
\text { Emotional, behavioral and } \\
\text { communicational } \\
\text { repetitive patterns related } \\
\text { to answering styles } \\
\text { Answering styles and } \\
\text { consequences }\end{array}$ & $\begin{array}{l}\text { To detect of the pattern of } \\
\text { response style according } \\
\text { to verbal and nonverbal } \\
\text { communication } \\
\text { To encourage the reflect } \\
\text { about consequences of } \\
\text { different styles } \\
\text { To promote connections } \\
\text { between answering styles } \\
\text { and certain situations }\end{array}$ & $\begin{array}{l}\text { Express and communicate } \\
\text { Role-playing } \\
\text { To comfort problems in an } \\
\text { assertive way: to express, to } \\
\text { point out the moment, to } \\
\text { characterize, to adapt the } \\
\text { feelings, to emphasize he } \\
\text { cooperation, to limit, to } \\
\text { postpone a conversation, to } \\
\text { empathize, to defend one's } \\
\text { feelings, a scratched disc, etc. }\end{array}$ \\
\hline
\end{tabular}

\section{Stage II: Designing Application Methodologies}

The second phase of program development focuses on the delimitation of methodologies for the application and effectiveness of the PIPATIC program. The CONSORT (Consolidated Standards of Reporting Trials) international guide (Schulz et al. 2010) was used to design the program. The CONSORT methodologies guarantee quality experimental or quasi-experimental studies: (i) design (clinical trial with randomization to avoid bias), (ii) dependent and independent variables and assessment instruments, (iii) inclusion and exclusion criteria, (iv) aims and hypothesis, (v) method, and (vi) ethics.

\section{PIPATIC Program}

\section{Target Population}

The target population of the PIPATIC program is the adolescents aged 12 to 18 years old.

\section{Clinical Objectives}

The main aim of the program is to provide specialized psychological assistance for adolescents with IGD. The clinical objectives are as follows: (i) to gain adaptive (rather than maladaptive) use of videogames and ICTs; (ii) to enable therapeutic change to different patient profiles; and (iii) to treat adolescents multidimensionally, attending to intrapersonal needs (including the comorbid disorders), interpersonal needs, family needs, and educational/occupational needs. 
Table 6 Module 5: family (three sessions)

\begin{tabular}{|c|c|c|c|}
\hline Sub-modules & Content & Psychological strategies & $\begin{array}{l}\text { Intervention techniques } \\
\text { and strategies }\end{array}$ \\
\hline $\begin{array}{l}\text { Family } \\
\text { communica- } \\
\text { tion }\end{array}$ & $\begin{array}{l}\text { Family communication } \\
\text { Communication } \\
\text { styles at home } \\
\text { Adaptive family } \\
\text { communication }\end{array}$ & $\begin{array}{l}\text { To contain negative } \\
\text { emotions and } \\
\text { anxieties related to } \\
\text { family conflicts } \\
\text { To detect } \\
\text { communicational } \\
\text { mistakes in the } \\
\text { family } \\
\text { To promote new } \\
\text { communication skills } \\
\text { in the family }\end{array}$ & $\begin{array}{l}\text { Active listening } \\
\text { Activities related to } \\
\text { adaptive communication } \\
\text { styles in the family } \\
\text { Application of the contents daily } \\
\text { Other specific activities }\end{array}$ \\
\hline $\begin{array}{l}\text { Limits } \\
\text { establish- } \\
\text { ment }\end{array}$ & $\begin{array}{l}\text { Family limits } \\
\text { Establishment of } \\
\text { news family limits } \\
\text { Family behaviors }\end{array}$ & $\begin{array}{l}\text { To guide the } \\
\text { identification of } \\
\text { family behaviors and } \\
\text { boundaries } \\
\text { To establish decisions } \\
\text { and new limits } \\
\text { through negotiation } \\
\text { strategies }\end{array}$ & $\begin{array}{l}\text { Specific activates related to this } \\
\text { sub-module, e.g., negotiation } \\
\text { techniques, remembering rules } \\
\text { without criticizing the others, } \\
\text { the use of consequences instead } \\
\text { of punishments }\end{array}$ \\
\hline $\begin{array}{l}\text { Bonds } \\
\text { establish- } \\
\text { ments }\end{array}$ & $\begin{array}{l}\text { Affective bounds: insecure } \\
\text { or ambivalent, avoidant, } \\
\text { disorganized and secure }\end{array}$ & $\begin{array}{l}\text { To detect the type of } \\
\text { family bond } \\
\text { To establish a new } \\
\text { adaptive bond } \\
\text { To improve family } \\
\text { bonds } \\
\text { To moderate the joint } \\
\text { effort decisions } \\
\text { To contain negative } \\
\text { aspects of the } \\
\text { therapy family }\end{array}$ & $\begin{array}{l}\text { Psychoeducation related to } \\
\text { affective bonds } \\
\text { Role-playing techniques with } \\
\text { the family } \\
\text { Specific homework to improve } \\
\text { new family skills and keep learnings } \\
\text { Specific activities related to showing } \\
\text { affection }\end{array}$ \\
\hline
\end{tabular}

Table 7 Module 6: creation of new lifestyle (two sessions)

\begin{tabular}{|c|c|c|c|}
\hline Sub-modules & Content & Psychological strategies & $\begin{array}{l}\text { Intervention techniques } \\
\text { and strategies }\end{array}$ \\
\hline $\begin{array}{l}\text { Observations } \\
\text { related to the } \\
\text { improvements }\end{array}$ & $\begin{array}{l}\text { Achieved goals } \\
\text { Achieved new skills }\end{array}$ & $\begin{array}{l}\text { To highlight the positive } \\
\text { changes and new } \\
\text { adaptive abilities } \\
\text { To give new strategies to keep } \\
\text { the changes during the time }\end{array}$ & $\begin{array}{l}\text { Comparatives self-registrations } \\
\text { Observations related to personal } \\
\text { changes and new skills } \\
\text { Balance between the previous and } \\
\text { the current situation }\end{array}$ \\
\hline $\begin{array}{r}\text { Alternative } \\
\text { activities }\end{array}$ & $\begin{array}{l}\text { To generate new } \\
\text { alternative } \\
\text { activities to } \\
\text { previous ones }\end{array}$ & $\begin{array}{l}\text { To promote the reflection of } \\
\text { the adolescent about } \\
\text { activities to develop next } \\
\text { To promote useful, positive } \\
\text { and social activities }\end{array}$ & $\begin{array}{l}\text { Developing a list about possible } \\
\text { new activities that generate } \\
\text { well-being and happiness }\end{array}$ \\
\hline $\begin{array}{l}\text { Relapse } \\
\text { prevention }\end{array}$ & Relapse prevention & $\begin{array}{l}\text { To explore current emotions } \\
\text { To point out risk situations } \\
\text { To provide specific ideas and } \\
\text { resources to avoid the } \\
\text { relapses }\end{array}$ & $\begin{array}{l}\text { Anticipation strategies to prevent } \\
\text { risk situations and relapses } \\
\text { Activities and relapse prevention } \\
\text { material }\end{array}$ \\
\hline
\end{tabular}


Table 8 Treatment conclusion and three-months follow-up

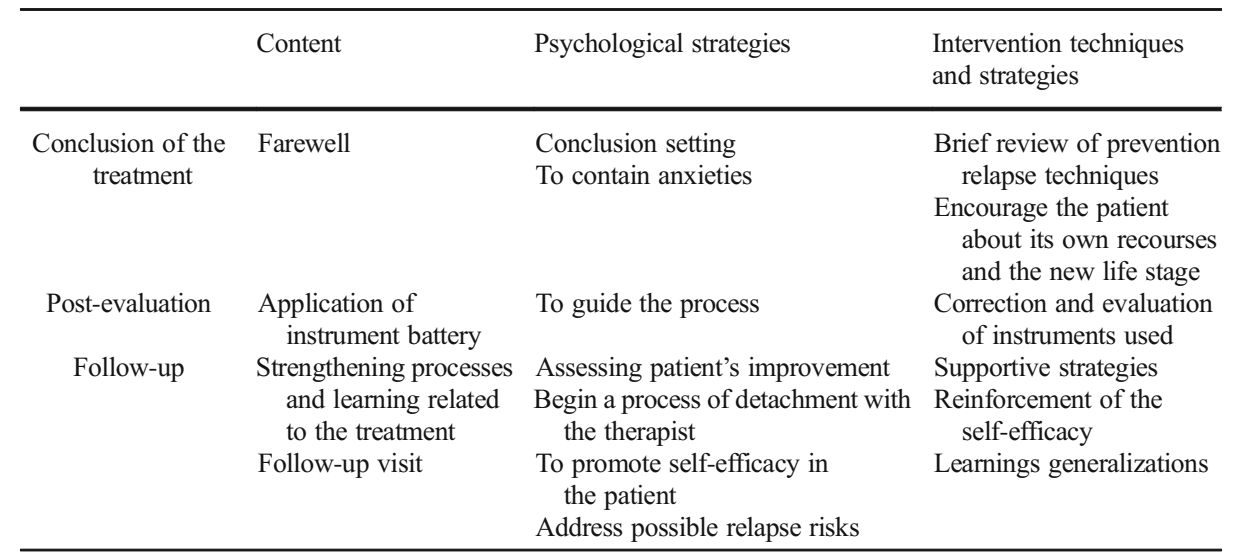

\section{Summary of the PIPATIC Manual}

The PIPATIC program was designed as a clinical manual comprising six modules with specific sub-modules. Each module includes several psychological techniques in addition to cross-psychotherapeutic strategies. The program is six month duration comprising twenty-two 45-minute weekly sessions each for both individuals and families. The PIPATIC intervention is an individual [person-to-person] therapy carried out by a qualified clinical psychologist. Before the commencement of treatment, several sessions are carried out with the following objectives: (i) to assess the inclusion and exclusion criteria, (ii) to talk to the patient and family and address any concerns they may have about the program, and (iii) to complete the first pre-treatment evaluation.

Tables 2, 3, 4, 5, 6, 7, and 8 summarize all the modules belonging to the PIPATIC program. The tables outline the main content, the psychological strategies used within the module, and the intervention techniques and strategies of every module. In addition, all the modules include therapeutic homework to strengthen the establishment related to the therapeutic changes required to help change everyday behavior. In the PIPATIC program, the direct collaboration of family in the treatment program is essential to make progress. It is uncommon for adolescents to ask for therapeutic help on their own (Griffiths 2015), and it is usually the adolescent's family who ask for therapeutic care or psychological treatment (King et al. 2010b).

The efficacy of the treatment program shows excellent promise based on data collected on the 17 individuals that have undergone the program to date (TorresRodríguez and Carbonell, 2015, 2017; Torres-Rodríguez, Griffiths and Carbonell, 2017). These preliminary results of the PIPATIC program pilot application demonstrate a reduction of time spent playing videogames, a reduction in IGD-related symptoms and comorbid symptoms, and improvement in multiple important areas in day-to-day functioning (e.g., interpersonal and intrapersonal functioning, family functioning, and educational/occupational functioning). Furthermore, compared to other treatments for IGD and Internet addiction published in the peer-reviewed literature, the PIPATIC program is arguably one of the most comprehensive treatment 


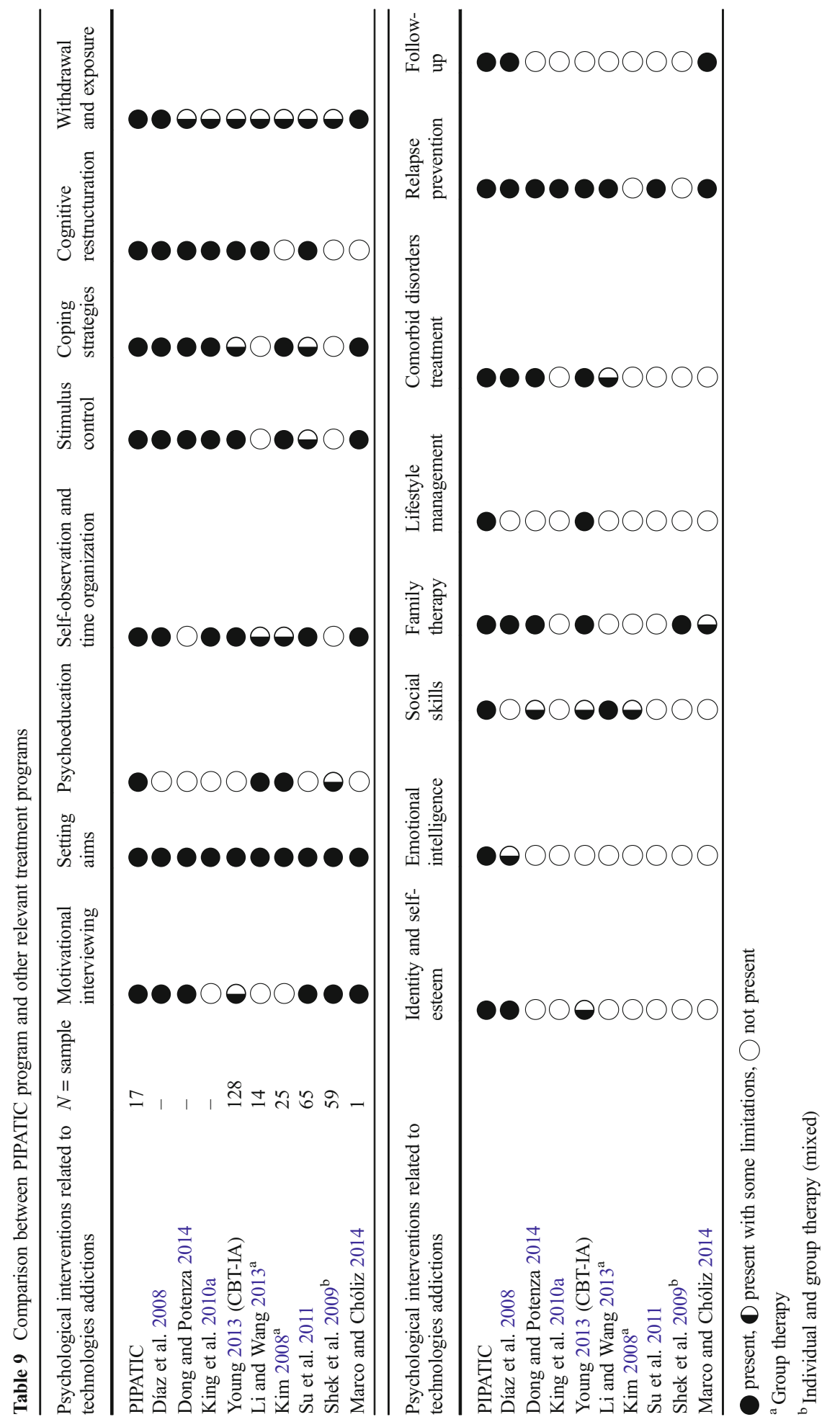


intervention for Internet and online videogame addiction (see Table 9 for an in-depth comparison between studies published in the empirical clinical literature).

\section{Conclusions}

The present paper described the development of the PIPATIC program, a contemporary and integrative treatment based on CBT for the specialized treatment of adolescents with IDG. Its design is based on a theoretical robust empirical base, on previous treatment studies, and on a combination of perspectives and psychotherapeutic strategies that have proven to be effective on adolescents across different disorders (Du et al. 2010; Fang-ru and Wei 2005; Han et al. 2015; King et al. 2012; Nathan 2015; Winkler et al. 2013; Young 2009, 2013).

At present, the efficacy of the program appears very promising but due to the time-intensive nature of the intervention, only 17 clients have completed treatment to date. As with any other treatment or manualized program, there are a number of limitations. The program was designed focusing on a very specific population (i.e., adolescents with IGD). The intervention has a specific rigidity because it must follow or adhere to specific methodological standards for its application and evaluation. Occasionally, such rigidity is difficult to adapt to the client's particular needs. Due to this, and to solve the "stiffness" of the treatment, the modules could be applied independently and in different order to adapt to the most urgent need that the client has. Despite these limitations, the preliminary results suggest the program is efficacious.

Future plans include (i) studying the effectiveness of PIPATIC treatment comparing the participants of this treatment with other participants receiving treatment as usual for addictions; (ii) comparing the data already collected in relation to pre-treatment, middletreatment, post-treatment, and three-months follow-up; and (iii) analyzing various cases of different ages, clinical profiles, game genre, and context to confirm the efficacy of findings in other populations and environments. It is expected that the PIPATIC program will continue to be an effective and pioneering integrative treatment for problematic use and addictive behaviors related to online videogames as well as concomitant pathologies. The present paper attempts to provide an orientation and update for health professionals in this field who want to treat adolescents for IGD.

Funding Information This study was supported by personal Blanquerna Research Grant (BRB) awarded to Alexandra Torres-Rodríguez (Universitat Ramon Llull, Barcelona).

\section{Compliance with Ethical Standards}

Informed Consent The study was approved by the ethics committee of Universitat Ramon Llull. Consent is not applicable because no data were collected for the present paper.

Conflict of Interest The authors' report no financial or any other conflicting relationship relevant to the topic of this paper. All authors' take responsibility for the integrity of the paper'scontent.

Open Access This article is distributed under the terms of the Creative Commons Attribution 4.0 International License (http:/creativecommons.org/licenses/by/4.0/), which permits unrestricted use, distribution, and reproduction in any medium, provided you give appropriate credit to the original author(s) and the source, provide a link to the Creative Commons license, and indicate if changes were made. 


\section{References}

American Psychiatric Association. (2013). DSM-5: diagnostic and statistical manual of mental disorders (5th ed.). Washington, DC: American Psychiatric Association.

Beck, A. T. (1979). Cognitive therapy and the emotional disorders. Boston: Penguin.

Beranuy, M., Carbonell, X., \& Griffiths, M. (2012). A qualitative analysis of online gaming addicts in treatment. International Journal of Mental Health and Addiction, 11(2), 149-161. https://doi.org/10.1007/s11469-0129405-2.

Carbonell, X., Fúster, H., Chamarro, A., \& Oberst, U. (2012). Adicción a internet y móvil: Una revisión de estudios empíricos españoles. Papeles Del Psicólogo, 33(2), 82-89.

Carbonell, X., Torres-Rodríguez, A., \& Fuster, H. (2016). El potencial adictivo de los videojuegos. In E. Echerburua (Ed.), Abuso de Internet: ¿antesala para la adicción al juego de azar on-line? Madrid: Síntesis.

Carroll, K. M., \& Nuro, K. F. (2002). One size cannot fit all: a stage model for psychotherapy manual development. Clinical Psychology: Science and Practice, 9(4), 396-406.

Díaz, R., Beranuy, M., \& Oberst, U. (2008). Terapia de la adicción a internet y video-juegos en niños y adolescentes. Revista de Psicoterapia, 19(73), 69-100.

Dong, G., \& Potenza, M. N. (2014). A cognitive-behavioral model of Internet gaming disorder: theoretical underpinnings and clinical implications. Journal of Psychiatric Research, 58, 7-11. https://doi.org/10.1016/j. jpsychires.2014.07.005.

Du, Y., Jiang, W., \& Vance, A. (2010). Longer term effect of randomized, controlled group cognitive behavioral therapy for Internet addiction in adolescent students in Shanghai. The Australian and New Zealand Journal of Psychiatry, 44, 129-134. https://doi.org/10.3109/00048670903282725.

Ellis, A. (1990). Special features of rational-emotive therapy. In W. Dryden \& R. DiGiuseppe (Eds.), A primer on rational-emotive therapy (pp. 79-93). Champaign: Research Press.

Fang-ru, Y., \& Wei, H. (2005). The effect of integrated psychosocial intervention on 52 adolescents with internet addiction disorder. Chinese Journal of Clinical Psychology, 13, 343-345.

Feng, W., Ramo, D. E., Chan, S. R., \& Bourgeois, J. A. (2017). Internet gaming disorder: trends in prevalence 1998-2016. Addictive Behaviors, 75(June), 17-24. https://doi.org/10.1016/j.addbeh.2017.06.010.

Ferguson, C., Coulson, M., \& Barnett, J. (2011). A meta-analysis of pathological gaming prevalence and comorbidity with mental health, academic and social problems. Journal of Psychiatric Research, 45(12), 1573-1578. https://doi.org/10.1016/j.jpsychires.2011.09.005.

Fuster, H., Carbonell, X., Pontes, H. M., \& Griffiths, M. D. (2016). Spanish validation of the Internet Gaming Disorder (IGD-20) Test. Computers in Human Behavior, 56, 215-224. https://doi.org/10.1016/j. chb.2015.11.050.

Gentile, D., Choo, H., Liau, A., Sim, T., Li, D., Fung, D., \& Khoo, A. (2011). Pathological video game use among youths: a two-year longitudinal study. Pediatrics, 127(2), 319-329. https://doi.org/10.1542 /peds.2010-1353.

Greenfield, D. N. (1999a). Virtual addiction: help for netheads, cyberfreaks, and those who love them. Oakland: New Harbin.

Greenfield, D. N. (1999b). Psychological characteristics of compulsive internet use: A preliminary analysis. Cyberpsychology \& Behavior, 2(5), 403-412. https://doi.org/10.1089/cpb.1999.2.403.

Griffiths, M. D. (2015). Problematic technology use during adolescence: why don't teenagers seek treatment? Education and Health, 33(1), 6-9.

Griffiths, M. D., \& Meredith, A. (2009). Videogame addiction and its treatment. Journal of Contemporary Psychotherapy, 39(4), 247-253. https://doi.org/10.1007/s10879-009-9118-4.

Griffiths, M. D., \& Nuyens, F. (2017). An overview of structural characteristics in problematic video game playing. Current Addiction Reports, 272-283. https://doi.org/10.1007/s40429-017-0162-y.

Griffiths, M. D., King, D. L., \& Demetrovics, Z. (2014). DSM-5 Internet gaming disorder needs a unified approach to assessment. Neuropsychiatry, 4(1), 1-4. https://doi.org/10.2217/npy.13.82.

Griffiths, M. D., Kuss, D. J., Billieux, J., \& Pontes, H. M. (2016a). The evolution of Internet addiction: a global perspective. Addictive Behaviors, 53, 193-195. https://doi.org/10.1016/j.addbeh.2015.11.001.

Griffiths, M. D., van Rooij, A. J., Kardefelt-Winther, D., Starcevic, V., Király, O., Pallesen, S., ... Demetrovics, Z. (2016b). Working towards an international consensus on criteria for assessing internet gaming disorder: a critical commentary on Petry et al. (2014). Addiction, 111(1), 167-175. https://doi.org/10.1111/add.13057.

Han, D. H., Lee, Y. S., Shi, X., \& Renshaw, P. F. (2014). Proton magnetic resonance spectroscopy (MRS) in online game addiction. Journal of Psychiatric Research, 58, 63-68.

Han, D., Kim, S. M., Lee, Y. S., \& Renshaw, P. F. (2015). The effect of family therapy on the changes in the severity of on-line game play and brain activity in adolescents with on-line game addiction. Psychiatry Research: Neuroimaging, 202(2), 126-131. https://doi.org/10.1016/j.pscychresns.2012.02.011.The. 
Hansen, N. B., \& Lambert, M. J. (2003). An evaluation of the dose-response relationship in naturalistic treatment settings using survival analysis. Mental Health Services Research, 5(1), 1-12. https://doi.org/10.1023 /A:1021751307358.

Hofmann, S. G., \& Barlow, D. H. (2014). Evidence-based psychological interventions and the common factors approach: the beginnings of a rapprochement? Psychotherapy, 51(4), 510-513. https://doi.org/10.1037/a0037045.

Hofmann, S. G., Asnaani, A., Vonk, I. J. J., Sawyer, A. T., \& Fang, A. (2012). The efficacy of cognitive behavioral therapy: a review of meta-analyses. Cognitive Therapy and Research, 36(5), 427-440. https://doi. org/10.1007/s10608-012-9476-1.The.

Huang, X., Li, M., \& Tao, R. (2010). Treatment of Internet addiction. Current Psychiatry Reports, 12(5), 462470. https://doi.org/10.1007/s11920-010-0147-1.

Kadera, S. W., Lambert, M. J., \& Andrews, A. A. (1996). How much therapy is really enough?: a session-bysession analysis of the psychotherapy dose-effect relationship. Journal of Psychotherapy Practice and Research, 5(2), 132-151.

Kaptsis, D., King, D. L., Delfabbro, P. H., \& Gradisar, M. (2016). Withdrawal symptoms in internet gaming disorder: a systematic review. Clinical Psychology Review, 43, 58-66. https://doi.org/10.1016/j. cpr.2015.11.006.

Kelleci, M., \& Inal, S. (2010). Psychiatric symptoms in adolescents with Internet use: comparison without Internet use. CyberPsychology, Behavior, and Social Networking, 13(2), 191-194.

Kelly, R. V. (2004). Massively multiplayer online role-playing games: the people, the addiction and the playing experience. Jefferson: McFarland.

Kim, J. U. (2008). The effect of a R/T group counseling program on the Internet addiction level and self-esteem of Internet addiction university students. International Journal of Reality Therapy, 27(2), 4-12.

King, D. L., \& Delfabbro, P. H. (2014). Internet gaming disorder treatment: a review of definitions of diagnosis and treatment outcome. Journal of Clinical Psychology, 70(10), 942-955. https://doi. org/10.1002/jclp.22097.

King, D. L., \& Delfabbro, P. H. (2016). Features of parent-child relationships in adolescents with Internet Gaming Disorder. International Journal of Mental Health and Addiction. https://doi.org/10.1007/s11469016-9699-6.

King, D., Delfabbro, P., \& Griffiths, M. (2010a). Cognitive behavioral therapy for problematic video game players: conceptual considerations and practice issues. Journal of Cyber Therapy and Rehabilitation, 3(3), 261-273.

King, D., Delfabbro, P., \& Griffiths, M. (2010b). Video game structural characteristics: a new psychological taxonomy. International Journal of Mental Health and Addiction, 8(1), 90-106.

King, D., Delfabbro, P., Griffiths, M., \& Gradisar, M. (2011). Assessing clinical trials of Internet addiction treatment: a systematic review and CONSORT evaluation. Clinical Psychology Review, 31(7), 1110-1116. https://doi.org/10.1016/j.cpr.2011.06.009.

King, D. L., Delfabbro, P. H., Griffiths, M. D., \& Gradisar, M. (2012). Cognitive-behavioral approaches to outpatient treatment of internet addiction in children and adolescents. Journal of Clinical Psychology, 68(11), 1185-1195. https://doi.org/10.1002/jclp.21918.

King, D. L., Delfabbro, P. H., \& Griffiths, M. D. (2013). Trajectories of problem video gaming among adult regular gamers: an 18-month longitudinal study. CyberPsychology, Behavior and Social Networking, 16(1), 72-76. https://doi.org/10.1089/cyber.2012.0062.

Király, O., Griffiths, M. D., \& Demetrovics, Z. (2015). Internet Gaming Disorder and the DSM-5: Conceptualization, debates, and controversies. Current Addiction Reports, 2(3), 254-262. https:/doi. org/10.1007/s40429-015-0066-7.

Kleinke, C. L. (1994). Common principles of psychotherapy. Pacific Grove: Brooks/Cole Pub Co..

Ko, C. H., Yen, J. Y., Chen, C. C., Chen, S. H., Wu, K., \& Yen, C. F. (2006). Tridimensional personality of adolescents with internet addiction and substance use experience. The Canadian Journal of Psychiatry, 51(14), 887-894.

Ko, C.-H., Yen, J.-Y., Chen, S.-H., Wang, P.-W., Chen, C.-S., \& Yen, C.-F. (2014). Evaluation of the diagnostic criteria of Internet gaming disorder in the DSM-5 among young adults in Taiwan. Journal of Psychiatric Research, 53, 103-110. https://doi.org/10.1016/j.jpsychires.2014.02.008.

Kowert, R., Festl, R., \& Quandt, T. (2014). Unpopular, overweight, and socially inept: reconsidering the stereotype of online gamers. CyberPsychology, Behavior and Social Networking, 17(3), 141-146. https://doi.org/10.1089/cyber.2013.0118.

Kuss, D. J., \& Griffiths, M. D. (2012a). Internet gaming addiction: a systematic review of empirical research. International Journal of Mental Health and Addiction, 10(2), 278-296. https://doi.org/10.1007/s11469-011-9318-5.

Kuss, D. J., \& Griffiths, M. D. (2012b). Online gaming addiction in children and adolescents: a review of empirical research. Journal of Behavioral Addictions, 1(1), 3-22. https://doi.org/10.1556/JBA.1.2012.1.1. 
Kuss, D. J., \& Griffiths, M. D. (2017). Social networking sites and addiction: ten lessons learned. https://doi. org/10.3390/ijerph14030311.

Kuss, D. J., Griffiths, M. D., \& Pontes, H. M. (2016). Chaos and confusion in DSM-5 diagnosis of Internet Gaming Disorder: issues, concerns, and recommendations for clarity in the field. Journal of Behavioral Addictions, 1-7. https://doi.org/10.1556/2006.5.2016.062.

Lambert, M. J., Shapiro, D. A., \& Bergin, A. E. (1994). The effectiveness of psychotherapy. In S. L. Garfield \& A. E. Bergin (Eds.), Handbook of psychotherapy and behavior change (pp. 157-211). New York: John Wiley \& Sons.

Laska, K. M., Gurman, A. S., \& Wampold, B. E. (2014). Expanding the lens of evidence-based practice in psychotherapy: a common factors perspective. Psychotherapy, 51(4), 467-481. https://doi.org/10.1037 /a0034332.

Li, H., \& Wang, S. (2013). The role of cognitive distortion in online game addiction among Chinese adolescents. Children and Youth Services Review, 35(9), 1468-1475. https://doi.org/10.1016/j.childyouth.2013.05.021.

Marco, C., \& Chóliz, M. (2014). Tratamiento cognitivo-conductual de la adicción a videojuegos de rol online. Anales de Psicologia, 30(1), 46-55.

Masten, A. S., \& Garmezy, N. (1985). Risk, vulnerability, and protective factors in developmental psychopathology. In A. S. Masten \& N. Garmezy (Eds.), Advances in clinical child psychology (pp. 1-52). Minnesota: Springer.

Mazurek, M. O., \& Engelhardt, C. R. (2013). Video game use in boys with autism spectrum disorder, ADHD, or typical development. Pediatrics, 132(2), 260-266. https://doi.org/10.1542/peds.2012-3956.

Moscosoa, S. C., Chaves, S. S., Vidal, M. P., \& Anguera, M. T. (2013). Reporting a program evaluation: needs, program plan, intervention, and decisions. International Journal of Clinical and Health Psychology, 13(1), 58-66. https://doi.org/10.1016/S1697-2600(13)70008-5.

Müller, K. W., Janikian, M., Dreier, M., Wölfling, K., Beutel, M. E., Tzavara, C., et al. (2015). Regular gaming behavior and internet gaming disorder in European adolescents: results from a cross-national representative survey of prevalence, predictors, and psychopathological correlates. European Child \& Adolescent Psychiatry, 24, 565-574. https://doi.org/10.1007/s00787-014-0611-2.

Nathan, P. E. (2015). A guide to treatments that work (4th ed.). New York: Oxford University Press.

Nuyens, F., Deleuze, J., Maurage, P., Griffiths, M. D., Kuss, D. J., \& Billieux, J. (2016). Impulsivity in Multiplayer Online Battle Arena Gamers: preliminary results on experimental and self-report measures. Journal of Behavioral Addictions, 5(2), 351-356. https://doi.org/10.1556/2006.5.2016.028.

Orzack, M. H., Voluse, A. C., Wolf, D., \& Hennen, J. (2006). An ongoing study of group treatment for men involved in problematic Internet-enabled sexual behavior. CyberPsychology \& Behavior, 9(3), 348-360. https://doi.org/10.1089/cpb.2006.9.348.

Pontes, H. M., Király, O., Demetrovics, Z., \& Griffiths, M. D. (2014). The conceptualisation and measurement of DSM-5 Internet Gaming Disorder: the development of the IGD-20 Test. PLoS One, 9(10), e110137. https://doi.org/10.1371/journal.pone.0110137.

Rehbein, F., Psych, G., Kleimann, M., Mediasci, G., \& Mößle, T. (2010). Prevalence and risk factors of video game dependency in adolescence: results of a German nationwide survey. CyberPsychology, Behavior, and Social Networking, 13(3), 269-277. https://doi.org/10.1089/cyber.2009.0227.

Rogers, C. (1959). A theory of therapy, personality and interpersonal relationships as developed in the clientcentered framework. In S. Koch (Ed.), Psychology: A study of a science. vol. 3: formulations of the person and the social context. New York: McGraw Hill.

Schulz, K. F., Altman, D. G., Moher, D., \& Group, C. (2010). CONSORT 2010 statement: updated guidelines for reporting parallel group randomized trials. Annals of Internal Medicine, 152(11), 726-732. https:/doi. org/10.7326/0003-4819-152-11-201006010-00232.

Seligman, M. E. (1995). The effectiveness of psychotherapy: the consumer reports study. American Psychologist, 50(12), 965-974.

Shapira, N. A., Goldsmith, T. D., Keck Jr., P. E., Khosla, U. M., \& McElroy, S. L. (2000). Psychiatric features of individuals with problematic internet use. Journal of Affective Disorders, 57, 267-272.

Shek, D., Tang, V., \& Lo, C. Y. (2009). Evaluation of an internet addiction treatment. Adolescence, 44(174), 359-373.

Steinhausen, H. C., \& Metzke, C. W. (2001). Risk, compensatory, vulnerability, and protective factors influencing mental health in adolescence. Journal of Youth and Adolescence, 30(3), 259-280.

Su, W., Fang, X., Miller, J. K., \& Wang, Y. (2011). Internet-based intervention for the treatment of online addiction for college students in China: a pilot study of the Healthy Online Self-helping Center. CyberPsychology, Behavior and Social Networking, 14(9), 497-503. https://doi.org/10.1089 /cyber.2010.0167.

Therien, P., Lavarenne, S. A., \& Lecomte, T. (2014). The treatment of complex dual disorders: clinicians' and service users' perspectives. Journal of Addiction Research and Therapy, 10(6), 2-7. https://doi.org/10.4172 /2155-6105.S10-006. 
Torres-Rodríguez, A., \& Carbonell, X. (2015). Adicción a los videojuegos en línea: Tratamiento mediante el programa PIPATIC. Aloma, 33(2), 67-75.

Torres-Rodriguez, A., \& Carbonell, X. (2017). Update and proposal of treatment for Internet Gaming Disorder: PIPATIC program. Revista de Psicoterapia, 28(107), 317-336.

Torres-Rodriguez, A., Griffiths, M. D., \& Carbonell, X. (2017). Internet gaming disorder treatment: A case study evaluation of four adolescent problematic gamers. Manuscript submitted for publication.

van Rooij, A. J., Kuss, D. J., Griffiths, M. D., Shorter, G. W., Schoenmakers, M. T., \& Van De Mheen, D. (2014). The (co-)occurrence of problematic video gaming, substance use, and psychosocial problems in adolescents. Journal of Behavioral Addictions, 3(3), 157-165. https://doi.org/10.1556/JBA.3.2014.013.

Williams, D., Yee, N., \& Caplan, S. E. (2008). Who plays, how much, and why? Debunking the stereotypical gamer profile. Journal of Computer-Mediated Communication, 13(4), 993-1018. https://doi.org/10.1111 j.1083-6101.2008.00428.x.

Winkler, A., Dörsing, B., Rief, W., Shen, Y., \& Glombiewski, J. A. (2013). Treatment of internet addiction: a meta-analysis. Clinical Psychology Review, 33(2), 317-329. https://doi.org/10.1016/j.cpr.2012.12.005.

Wittek, C. T., Finserås, T. R., Pallesen, S., Mentzoni, R. A., Hanss, D., Griffiths, M. D., \& Molde, H. (2015). Prevalence and predictors of video game addiction: a study based on a national representative sample of gamers. International Journal of Mental Health and Addiction. https://doi.org/10.1007/s11469-015-9592-8.

Wölfling, K., Beutel, M. E., Dreier, M., \& Müller, K. W. (2014). Treatment outcomes in patients with Internet addiction: a clinical pilot study on the effects of a cognitive-behavioral therapy program. BioMed Research International, 2014.

Wood, R. T. A., Griffiths, M. D., Chappell, D., \& Davies, M. N. O. (2004). The structural characteristics of video games: a psycho-structural analysis. CyberPsychology \& Behavior, 7(1), 1-10. https://doi.org/10.1089 /109493104322820057.

Yee, N. (2006). The demographics, motivations and derived experiences of users of massively multi-user online graphical environments. Presence Teleoperators and Virtual Environments, 15, 309-329.

Young, K. S. (2007). Cognitive behavior therapy with Internet addicts: treatment outcomes and implications. CyberPsychology \& Behavior, 10(5), 671-679. https://doi.org/10.1089/cpb.2007.9971.

Young, K. (2009). Understanding online gaming addiction treatment issues for adolescents. The American Journal of Family Therapy, 37, 355-372.

Young, K. S. (2013). Treatment outcomes using CBT-IA with Internet-addicted patients. Journal of Behavioral Addictions, 2(4), 209-215. https://doi.org/10.1556/JBA.2.2013.4.3. 